\title{
Acrocallosal syndrome
}

INSERM

\section{Source}

INSERM. (1999). Orphanet: an online rare disease and orphan drug data base.

Acrocallosal syndrome. ORPHA:36

Acrocallosal syndrome (ACS) is a polymalformative syndrome characterized by agenesis

of corpus callosum (CC), distal anomalies of limbs, minor craniofacial anomalies and intellectual deficit. 